\title{
Influence of Soybean (Glycine max) Population and Herbicide Program on Palmer Amaranth (Amaranthus palmeri) Control, Soybean Yield, and Economic Return
}

\author{
Amy E. Hoffner, David L. Jordan, Alan C. York, E. James Dunphy, and Wesley J. Everman \\ Department of Crop Science, North Carolina State University, P.O. Box 7620, Raleigh, NC 27695-7620, USA \\ Correspondence should be addressed to David L. Jordan, david_jordan@ncsu.edu
}

Received 1 July 2012; Accepted 7 August 2012

Academic Editors: D. Chikoye, O. Ferrarese-Filho, Y. I. Kuk, and W. P. Williams

Copyright ( $) 2012$ Amy E. Hoffner et al. This is an open access article distributed under the Creative Commons Attribution License, which permits unrestricted use, distribution, and reproduction in any medium, provided the original work is properly cited.

\begin{abstract}
Palmer amaranth (Amaranthus palmeri S. Wats) has become one of the most prominent and difficult weeds to control in soybean (Glycine max (L.) Merr.) in North Carolina. A survey was conducted in North Carolina during fall 2010 to estimate the magnitude of this problem. Palmer amaranth was present in $39 \%$ of 2,512 fields representing $0.24 \%$ of soybean ha in North Carolina. In recent years, growers have reduced soybean seeding rates in an effort to decrease production costs associated with technology fees. However, given the increase in prevalence of Palmer amaranth and the difficultly in controlling this weed due to herbicide resistance, growers may need to reconsider reductions in seeding rates. Therefore, research was conducted during 2010 and 2011 to determine if Palmer amaranth control, soybean yield, and economic return were affected by soybean plant population, preemergence (PRE) and postemergence (POST) herbicides, and herbicide resistant traits (glufosinate-resistant and glyphosateresistant cultivars). Applying PRE or POST herbicides and increasing soybean population increased Palmer amaranth control, soybean yield, and economic return when compared with POST herbicides only or when lower soybean populations were present. Efficacy of glufosinate and glyphosate did not vary in most instances, most likely because these herbicides were applied timely, and the frequency of glyphosate resistance did not exceed $10 \%$ in these fields.
\end{abstract}

\section{Introduction}

Effective weed management continues to be an important component of profitable soybean production in North Carolina. In recent years, herbicide-resistant weed populations have developed and have limited the effectiveness of herbicide options for growers. Populations of Palmer amaranth and horseweed (Conyza canadensis L.) in the coastal plain of North Carolina resistant to glyphosate have been confirmed $[1,2]$. Resistance of Palmer amaranth to acetolactate synthase (ALS)-inhibiting herbicides also has been confirmed in North Carolina $[1,2]$. Managing herbicideresistant weed populations continues to be a challenge, especially Palmer amaranth, where alternatives to glyphosate and ALS-inhibiting herbicides require timely application $[3,4]$. During fall 2010, 242 specific sites were sampled in North Carolina to determine the geographical range of Palmer amaranth and to determine if these populations were resistant to glyphosate. Of these specific sites, $52 \%$ had Palmer amaranth present with $98 \%$ of these populations expressing resistance to glyphosate and $85 \%$ expressing resistance to thifensulfuron-methyl [5]. Glyphosate-resistant Palmer amaranth has become the most challenging weed in cotton (Gossypium hirsutum L.) and soybean production in the southeastern United States [6-8].

Cultural practices, such as cultivar selection, row pattern, and plant populations, can influence weed management $[9,10]$. Residual herbicides applied PRE and POST herbicides other than glyphosate are important in managing glyphosate-resistant Palmer amaranth in soybean [11-13]. Glufosinate applied to glufosinate-resistant cultivars is an alternative to glyphosate for control of Palmer amaranth. 
TABLE 1: Planting date, soybean plant population, dates of preemergence and postemergence herbicide application, and estimated level of resistance to glyphosate at Rocky Mount during 2010 and 2011.

\begin{tabular}{|c|c|c|c|c|c|c|c|}
\hline \multirow{3}{*}{ Year } & \multirow{3}{*}{ Field } & \multirow{3}{*}{ Planting date } & \multicolumn{2}{|c|}{ Soybean population } & \multicolumn{2}{|c|}{ Date of herbicide application } & \multirow{3}{*}{$\begin{array}{l}\text { Resistance to } \\
\text { glyphosate }^{\mathrm{a}}\end{array}$} \\
\hline & & & Low & High & Preemergence & Postemergence & \\
\hline & & & \multicolumn{2}{|c|}{ Plants ha ${ }^{-1}$} & & & \\
\hline 2010 & B13 & May 24 & 122,000 & 342,000 & May 24 & June 10 & Yes $(5 \%)$ \\
\hline 2010 & E2 & May 24 & 145,000 & 464,000 & May 24 & June 10 & No \\
\hline 2011 & B13 & June 7 & 221,000 & 560,000 & June 7 & June 21 & Yes $(5 \%)$ \\
\hline 2011 & $\mathrm{C} 11$ & June 7 & 208,000 & 519,000 & June 7 & June 21 & Yes $(10 \%)$ \\
\hline 2011 & E3 & June 7 & 193,000 & 533,000 & June 7 & June 21 & No \\
\hline
\end{tabular}

${ }^{a}$ Resistance to glyphosate was not confirmed in these fields but has been confirmed previously at this location during 2008; percentages refer to estimated percent of Palmer amaranth population surviving glyphosate application.

TABLE 2: Palmer amaranth population as affected by preemergence herbicides at Rocky Mount, NC, during 2010 and $2011 .^{\mathrm{a}}$

\begin{tabular}{lcccc}
\hline Year & Field & No preemergence herbicide & $\begin{array}{c}\text { Palmer amaranth population } \\
\text { S-metolachlor } \\
\text { Plants m }{ }^{-2}\end{array}$ & S-metolachlor plus fomesafen \\
\hline 2010 & B13 & $124 \mathrm{a}$ & $4 \mathrm{~b}$ & $1 \mathrm{~b}$ \\
2010 & E2 & $165 \mathrm{a}$ & $10 \mathrm{~b}$ & $6 \mathrm{~b}$ \\
2011 & B13 & $74 \mathrm{a}$ & $5 \mathrm{~b}$ & $0 \mathrm{~b}$ \\
2011 & C11 & $163 \mathrm{a}$ & $4 \mathrm{~b}$ & $0 \mathrm{~b}$ \\
2011 & E3 & $76 \mathrm{a}$ & $5 \mathrm{~b}$ & $0 \mathrm{~b}$ \\
\hline
\end{tabular}

${ }^{a}$ Means within a year and field combination followed by the same letter are not significantly different based on Fisher's Protected LSD test at $P \leq 0.05$. Data are pooled over soybean populations and herbicide resistance traits. Postemergence herbicides have not been applied when Palmer amaranth density was recorded.

Developing a strategy for controlling Palmer amaranth that is as sustainable and effective as programs in glyphosateresistant crops has become one of the most important weed management challenges in the southeastern United States [11-13].

In North Carolina, soybean at populations below those established in many fields yield as well as higher populations considered "standard" (exceeding 300,000 plants $\mathrm{ha}^{-1}$ ) by the farming community (Dunphy, E. J., personal communication). Reducing input costs in soybean by using lower seeding rates, especially when transgenic cultivars are planted which include substantial technology fees, is a reasonable approach to soybean production. While research has demonstrated that higher plant populations and narrow rows suppress weeds more effectively than lower plant populations or production in wider row spacings [1417], Norsworthy and Oliver [18] reported that applying a second application of glyphosate was more economical than increasing the seeding rate. Kratochvil et al. [19] reported that a population $80 \%$ of a traditional seeding rate $(345,000$ plants ha ${ }^{-1}$ versus 432,500 seed ha ${ }^{-1}$ ) increased profit from $\$ 14$ to $\$ 28 \mathrm{ha}^{-1}$. However, under high populations of weeds, and most especially glyphosate-resistant Palmer amaranth, there is concern that lower populations will be susceptible to greater weed interference and possibly lower yield. Owen [12] indicated that increased difficulty in controlling weeds with glyphosate most likely will occur due to prolonged use of glyphosate. Guillermo et al. [14] suggested that higher seeding rates should be used in fields where weeds are difficult to control due to shifts in populations or development of herbicide resistance within weed communities. Given that Palmer amaranth resistance to glyphosate has increased dramatically in North Carolina $[2,5]$, research is needed to better define the role of seeding rate on weed management programs for soybean. Therefore, research was conducted at five locations in North Carolina during 2010 and 2011 to compare Palmer amaranth control, soybean yield, and economic return with combinations of PRE and POST herbicides applied to glufosinate- and glyphosateresistant cultivars at two soybean populations. A survey of fields to determine the extent of Palmer amaranth infestation also was conducted during 2010 within the latter portion of the growing season.

\section{Materials and Methods}

2.1. Survey of Soybean Fields in North Carolina. A total of 2,512 soybean fields in North Carolina were surveyed during 2010 from mid August through September to determine the extent of Palmer amaranth escapes. The area represented in these fields was $0.24 \%$ of the 62,700 ha of soybean harvested in North Carolina during 2010 [20]. The procedure involved estimating the percentage of total ha within each field with at least one Palmer amaranth plant present. The survey did not involve walking or driving across soybean fields but was a result of viewing the field from one side. Although the average field size in the survey was $6.2 \mathrm{ha}$, this procedure most likely under estimated infestation in some fields. The 
TABle 3: The influence of herbicide resistance trait, soybean plant population, and preemergence herbicide on Palmer amaranth control 2 weeks after POST application in Field E2 during 2010. ${ }^{\mathrm{a}}$

\begin{tabular}{|c|c|c|c|}
\hline \multirow{3}{*}{ Soybean population ${ }^{\mathrm{b}}$} & \multirow{3}{*}{ Preemergence herbicides $^{c}$} & \multicolumn{2}{|c|}{$\begin{array}{l}\text { Palmer amaranth control } \\
\text { Herbicide resistance trait }\end{array}$} \\
\hline & & Glyphosate & Glufosinate \\
\hline & & \multicolumn{2}{|c|}{$\%$} \\
\hline Low & None & $43 c$ & $34 \mathrm{~d}$ \\
\hline Low & $S$-metolachlor & $73 b$ & $74 \mathrm{~b}$ \\
\hline Low & $S$-metolachlor plus fomesafen & $86 a$ & $82 \mathrm{a}$ \\
\hline High & None & $49 c$ & $49 \mathrm{c}$ \\
\hline High & $S$-metolachlor & $84 \mathrm{ab}$ & $77 \mathrm{~b}$ \\
\hline High & $S$-metolachlor plus fomesafen & $93 \mathrm{a}$ & $97 \mathrm{a}$ \\
\hline
\end{tabular}

TABLE 4: The influence of herbicide resistance trait, preemergence herbicide, and postemergence herbicide on Palmer amaranth control 2 weeks after POST application in Field E2 during 2010. ${ }^{\mathrm{a}}$

\begin{tabular}{|c|c|c|c|}
\hline \multirow{3}{*}{ Preemergence herbicide ${ }^{\mathrm{b}}$} & \multirow{3}{*}{ Postemergence herbicide } & \multicolumn{2}{|c|}{$\begin{array}{l}\text { Palmer amaranth control } \\
\text { Herbicide resistance trait }^{c}\end{array}$} \\
\hline & & Glufosinate & Glyphosate \\
\hline & & \multicolumn{2}{|c|}{$\%$} \\
\hline None & No & $0 \mathrm{e}$ & od \\
\hline$S$-metolachlor & No & $33 \mathrm{~d}$ & $54 \mathrm{~b}$ \\
\hline$S$-metolachlor plus fomesafen & No & $62 b$ & $46 c$ \\
\hline None & Yes & $46 c$ & $59 \mathrm{~b}$ \\
\hline$S$-metolachlor & Yes & $64 \mathrm{ab}$ & $81 \mathrm{a}$ \\
\hline$S$-metolachlor plus fomesafen & Yes & $70 \mathrm{a}$ & $85 a$ \\
\hline
\end{tabular}

percentage of ha with Palmer amaranth was grouped into fields with up to $50 \%$ of ha infested and fields with more than $50 \%$ of ha infested.

\subsection{Interactions of Plant Population, Herbicide Resistant Trait,} and Herbicide Program. The experiment was conducted in five fields in North Carolina during 2010 and 2011 at the Upper Coastal Plain Research Station near Rocky Mount in fields with natural and relatively high populations of Palmer amaranth. Although other weed species were present, populations were low and inconsistent across fields compared with density and distribution of Palmer amaranth. The experiment was conducted during both years in one field (referred to as Field B13) consisting of a Lynchburg fine sandy loam soil (fine-loamy, siliceous, semiactive, thermic Aeric Paleaquults). The experiment was also conducted in Field E2 (2010) and Field E3 (2011) consisting of the same soil series. A final experiment in 2011 was conducted in Field C11 consisting of a Nahunta loam (fine-silty, siliceous, subactive, thermic Aeric Paleaquults). Soybean was planted after disking and field cultivation in rows spaced $20 \mathrm{~cm}$ apart.
Plot size was 12 rows by $9 \mathrm{~m}$ in length. In 2010, soil moisture conditions were marginal for soybean emergence at planting and resulted in lower than desired populations but adequate for production. Soil conditions at planting during 2011 were very dry and fields were irrigated with a traveling gun system delivering $1.5 \mathrm{~cm}$ within $3 \mathrm{~d}$ after planting to ensure uniform emergence.

Treatments consisted of two levels of herbicide resistance trait (cultivars expressing either glyphosate- or glufosinateresistance) (HRT), two levels of soybean population (referred to as low or high), three levels of PRE herbicide (none, $S$ metolachlor, $S$-metolachlor plus fomesafen), and two levels of POST herbicide (none and a single POST application). The glufosinate-resistant cultivar was LL 595 N (Southern States Cooperative, Inc., 9120 W. Marlboro St., Farmville, NC 27828). The glyphosate-resistant cultivar was AG5605 (Monsanto Company, St. Louis, MO 63107). S-metolachlor (Dual II Magnum herbicide, Syngenta Crop Protection, Greensboro, NC 27709) and S-metolachlor plus fomesafen (Prefix herbicide, Syngenta Crop Protection, Greensboro, NC 27709) were applied at 1500 and $1200+270 \mathrm{~g}^{\mathrm{ae} \mathrm{ha}} \mathrm{ha}^{-1}$, 
TABLE 5: The influence of preemergence and postemergence herbicides on Palmer amaranth control 2 weeks after POST application. ${ }^{\mathrm{a}}$

\begin{tabular}{|c|c|c|c|c|}
\hline \multirow[b]{2}{*}{ Preemergence herbicides ${ }^{b}$} & \multirow[b]{2}{*}{ Postemergence herbicides ${ }^{\mathfrak{c}}$} & \multirow{2}{*}{$\begin{array}{l}2010 \\
\text { Field B13 }\end{array}$} & \multicolumn{2}{|c|}{2011} \\
\hline & & & $\begin{array}{c}\text { Field B13 } \\
\%\end{array}$ & Field C11 \\
\hline None & No & $6 \mathrm{~d}$ & ob & $14 \mathrm{~d}$ \\
\hline$S$-metolachlor & No & $65 c$ & $92 \mathrm{a}$ & $62 c$ \\
\hline$S$-metolachlor plus fomesafen & No & $88 \mathrm{ab}$ & $99 a$ & $90 b$ \\
\hline None & Yes & $82 b$ & $93 a$ & $65 c$ \\
\hline$S$-metolachlor & Yes & $89 \mathrm{ab}$ & $100 \mathrm{a}$ & $87 \mathrm{~b}$ \\
\hline$S$-metolachlor plus fomesafen & Yes & $91 \mathrm{a}$ & $100 \mathrm{a}$ & $98 \mathrm{a}$ \\
\hline
\end{tabular}

${ }^{a}$ Means within a year and field followed by the same letter are not significantly different according to Fisher's Protected LSD test at $P \leq 0.05$. Data are pooled over herbicide resistance traits and soybean populations.

${ }^{\mathrm{b}} \mathrm{S}$-metolachlor and $S$-metolachlor plus fomesafen applied at 1500 and $1200+270 \mathrm{~g} \mathrm{ha}^{-1}$, respectively.

${ }^{\mathrm{c}}$ Glufosinate and glyphosate applied to appropriate herbicide-resistant cultivar at 560 and $840 \mathrm{~g} \mathrm{ha}^{-1}$, respectively.

TABLE 6: Palmer amaranth control 2 weeks after POST application as influenced by herbicide resistance trait and preemergence herbicide treatment during 2010 in Field B13. ${ }^{\mathrm{a}}$

Preemergence herbicide ${ }^{b}$

Glufosinate

Palmer amaranth control

Herbicide resistance trait ${ }^{c}$

$\%$

\begin{tabular}{lll}
\hline None & $49 \mathrm{c}$ & $29 \mathrm{c}$ \\
$S$-metolachlor & $78 \mathrm{~b}$ & $71 \mathrm{~b}$ \\
$S$-metolachlor plus fomesafen & $94 \mathrm{a}$ & $93 \mathrm{a}$ \\
\hline
\end{tabular}

${ }^{a}$ Means within a herbicide resistance trait followed by the same letter are not significantly different according to Fisher's Protected LSD test at $P \leq 0.05$. Data are pooled over soybean population.

${ }^{\mathrm{b}} S$-metolachlor and $S$-metolachlor plus fomesafen applied at 1500 and $1200+270 \mathrm{~g} \mathrm{ha}^{-1}$, respectively.

${ }^{\mathrm{C}}$ Glufosinate and glyphosate applied to appropriate herbicide-resistant cultivar at 560 and $840 \mathrm{~g} \mathrm{ha}^{-1}$, respectively.

TABLE 7: The influence of herbicide resistance trait, soybean population, and preemergence and postemergence herbicides on Palmer amaranth control 2 weeks after post application in Field E3 during 2011. ${ }^{\mathrm{a}}$

\begin{tabular}{|c|c|c|c|c|}
\hline \multirow{3}{*}{ Soybean population ${ }^{\mathrm{b}}$} & \multicolumn{2}{|c|}{ Herbicide application timing } & \multicolumn{2}{|c|}{$\begin{array}{l}\text { Palmer amaranth control } \\
\text { Herbicide resistance trait }\end{array}$} \\
\hline & Preemergence $^{c}$ & Postemergence & Glufosinate & Glyphosate \\
\hline & & & \multicolumn{2}{|c|}{$\%$} \\
\hline Low & None & No & $0 \mathrm{~d}$ & $0 \mathrm{~d}$ \\
\hline Low & $S$-metolachlor & No & $83 \mathrm{bc}$ & $85 b c$ \\
\hline Low & $S$-metolachlor plus fomesafen & No & $95 \mathrm{ab}$ & $100 \mathrm{a}$ \\
\hline Low & None & Yes & $76 c$ & $78 \mathrm{c}$ \\
\hline Low & $S$-metolachlor & Yes & $98 \mathrm{a}$ & $100 \mathrm{a}$ \\
\hline Low & $S$-metolachlor plus fomesafen & Yes & $100 \mathrm{a}$ & $100 \mathrm{a}$ \\
\hline High & None & No & $0 \mathrm{~d}$ & $0 \mathrm{~d}$ \\
\hline High & $S$-metolachlor & No & $98 \mathrm{a}$ & $98 \mathrm{a}$ \\
\hline High & $S$-metolachlor plus fomesafen & No & $95 \mathrm{ab}$ & $100 \mathrm{a}$ \\
\hline High & None & Yes & $85 b c$ & $85 b c$ \\
\hline High & $S$-metolachlor & Yes & $100 \mathrm{a}$ & $100 \mathrm{a}$ \\
\hline High & $S$-metolachlor plus fomesafen & Yes & $100 \mathrm{a}$ & $100 \mathrm{a}$ \\
\hline
\end{tabular}

${ }^{a}$ Means within a HRT followed by the same letter are not significantly different according to Fisher's Protected LSD test at $P \leq 0.05$.

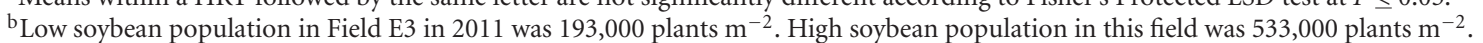

${ }^{\mathrm{c} S}$-metolachlor and $S$-metolachlor plus fomesafen applied at 1500 and $1200+270 \mathrm{~g} \mathrm{ha}^{-1}$, respectively.

${ }^{\mathrm{d}}$ Glufosinate and glyphosate applied to appropriate herbicide-resistant cultivar at 560 and $840 \mathrm{~g} \mathrm{ha}^{-1}$, respectively. 
TABLE 8: Soybean yield as influenced by soybean population and preemergence herbicide in Field E2 during 2010 and Field E3 during 2011. ${ }^{\mathrm{a}}$

\begin{tabular}{|c|c|c|}
\hline \multirow{3}{*}{ Treatment factor } & 2010 & 2011 \\
\hline & Field E2 & Field E3 \\
\hline & \multicolumn{2}{|c|}{$\mathrm{kg} \mathrm{ha}^{-1}$} \\
\hline \multicolumn{3}{|l|}{ Soybean population ${ }^{\mathrm{b}}$} \\
\hline Low & $200 \mathrm{~b}$ & $2210 b$ \\
\hline High & $430 \mathrm{a}$ & $3310 \mathrm{a}$ \\
\hline \multicolumn{3}{|l|}{ Preemergence herbicide ${ }^{c}$} \\
\hline None & $250 \mathrm{~b}$ & $1910 \mathrm{~b}$ \\
\hline$S$-metolachlor & $350 \mathrm{a}$ & $3130 \mathrm{a}$ \\
\hline$S$-metolachlor plus fomesafen & $340 \mathrm{a}$ & $3240 \mathrm{a}$ \\
\hline
\end{tabular}

${ }^{a}$ Means within a field and treatment factor followed by the same letter are not significantly different according to Fisher's Protected LSD test at $P \leq$ 0.05 .

${ }^{\mathrm{b}}$ Low soybean populations in Fields E2 (2010) and E3 (2011) were 145,000 and 193,000 plants ha ${ }^{-1}$, respectively. High soybean populations in these respective fields were 464,000 and 533,000 plants ha ${ }^{-1}$.

${ }^{\mathrm{c} S}$-metolachlor and $S$-metolachlor plus fomesafen applied at 1500 and 1200 $+270 \mathrm{~g} \mathrm{ha}^{-1}$, respectively.

TABle 9: Estimated economic return as influenced by soybean population, preemergence herbicide, or postemergence herbicide in Field E3 during 2011. ${ }^{\mathrm{a}}$

\begin{tabular}{lc}
\hline Treatment factor & $\begin{array}{c}\text { Economic return } \\
\$ \mathrm{ha}^{-1}\end{array}$ \\
\hline $\begin{array}{l}\text { Soybean population } \\
\text { b }\end{array}$ & $585 \mathrm{~b}$ \\
$\quad$ Low & $1017 \mathrm{a}$ \\
High & \\
Preemergence herbicide & \\
$\quad$ None & $415 \mathrm{~b}$ \\
S-metolachlor & $962 \mathrm{a}$ \\
S-metolachlor plus fomesafen & $1026 \mathrm{a}$ \\
Postemergence herbicide & \\
No & $562 \mathrm{~b}$ \\
Yes & $1039 \mathrm{a}$ \\
\hline
\end{tabular}

${ }^{a}$ Means within a treatment factor followed by the same letter are not significantly different according to Fisher's Protected LSD test at $P \leq 0.05$.

${ }^{b}$ Low and high soybean populations in Field E3 during 2011 were 193,000 and 533,000 plants $\mathrm{m}^{-2}$, respectively.

${ }^{\mathrm{c} S}$-metolachlor and $S$-metolachlor plus fomesafen applied at 1500 and 1200 $+270 \mathrm{~g} \mathrm{ha}^{-1}$, respectively.

${ }^{\mathrm{d}}$ Postemergence herbicides included glufosinate and glyphosate applied to appropriate herbicide-resistant cultivars at 560 and $840 \mathrm{~g} \mathrm{ha}^{-1}$, respectively.

respectively. Glufosinate-ammonium (Ignite 280 herbicide, Bayer CropScience, Research Triangle Park, NC 27709) and potassium salt of glyphosate (Roundup PowerMAX herbicide Monsanto Company, St. Louis, MO 63107) were applied at $560 \mathrm{~g}$ and $840 \mathrm{~g}_{\text {ae }} \mathrm{ha}^{-1}$, respectively. Herbicides were applied using a $\mathrm{CO}_{2}$-pressurized backpack sprayer calibrated to deliver $145 \mathrm{~L} \mathrm{ha}^{-1}$ using 8002 regular flat-fan nozzles (Teejet Corporation, Wheaton, IL 60187) at $275 \mathrm{kPa}$. Planting dates, dates of herbicide application, and soybean populations are listed in Table 1.
Soybean and Palmer amaranth densities were determined 2 weeks after planting immediately prior to POST herbicide application by counting plants in two, 0.5-m randomly selected areas within each plot (Tables 1 and 2). Visible estimates of percent Palmer amaranth control were recorded 2 and 8 weeks after POST herbicides were applied using a scale of 0 to 100 , where $0=$ no control and $100=$ complete control. Soybean yield was determined, and estimated economic return was calculated based on North Carolina Cooperative Extension Service enterprise budgets [21]. Seed, overhead, management, and weed control costs were removed from the budget to establish a base production cost of $\$ 393 \mathrm{ha}^{-1}$. Appropriate seed, herbicide, and application costs were then added based on treatments in the experiment. Seed cost was determined based on $\$ 99 \mathrm{ha}^{-1}$ for a seeding rate of 345,800 plants ha $^{-1}$ for both cultivars. Cost of $S$-metolachlor, $S$-metolachlor plus fomesafen, glufosinate, and glyphosate were set at $\$ 41 \mathrm{ha}^{-1}, \$ 42 \mathrm{ha}^{-1}, \$ 45 \mathrm{ha}^{-1}$, and $\$ 15 \mathrm{ha}^{-1}$, respectively. Application cost was $\$ 9.88 \mathrm{ha}^{-1}$. Soybean price was set at $\$ 0.44 \mathrm{~kg}^{-1}$.

The experimental design was a split-plot with HRT serving as whole plot units and combinations of soybean populations and herbicide treatments serving as sub-plot units. Treatments were replicated four times. Data for Palmer amaranth control, soybean yield, and estimated economic return were subjected to ANOVA using the Proc GLM procedure in SAS (SAS Institute, GLM Procedure, 100 Campus Drive, Cary, NC 27513) by experiment (combination of field and year) for a two (HRT) by two (soybean population) by three (PRE herbicide treatment) by two (POST herbicide treatment) factorial arrangement of treatments. Palmer amaranth control 2 weeks after POST herbicide application generally reflected control 8 weeks after POST herbicide application and will be the only visible ratings discussed. Significant year and field interactions were noted for Palmer amaranth control, soybean yield, and estimated economic return. Therefore, data are presented individually by year/field combination. Means of significant main effects and interactions were separated using Fisher's Protected LSD test at $P \leq 0.05$. Main effects and interactions not stated in the text exceeded $P=0.05$.

\section{Results and Discussion}

3.1. Survey of Soybean Fields in North Carolina. The percentage of ha within the 2,512 fields with at least one Palmer amaranth plant in the field was estimated to be $39 \%$ with $61 \%$ not having Palmer amaranth present (data not shown in tables). The percentage of fields with between 1 and $50 \%$ of ha infested was $22 \%$ while $17 \%$ of fields were infested at a level of 51 to $100 \%$ by Palmer amaranth (data not presented in tables). Results from this survey, combined with those of Hoffner et al. [5], reveal the magnitude of Palmer amaranth infestation in North Carolina.

3.2. Interactions of Plant Population, Herbicide Resistant Trait, and Herbicide Program. Palmer amaranth population in absence of PRE herbicides ranged from 74 to 165 plants $\mathrm{m}^{-2}$ (Table 2). When $S$-metolachlor or $S$-metolachlor plus 
TABLE 10: Soybean yield and estimated economic return as influenced by preemergence and postemergence herbicide treatments during 2011 in Fields B13 and C11.

\begin{tabular}{|c|c|c|c|c|c|}
\hline \multirow{3}{*}{ Preemergence herbicides ${ }^{\mathrm{b}}$} & \multirow{3}{*}{ Postemergence herbicides ${ }^{c}$} & \multicolumn{2}{|c|}{ Soybean yield } & \multicolumn{2}{|c|}{ Economic return } \\
\hline & & Field B13 & Field C11 & Field B13 & Field C11 \\
\hline & & \multicolumn{2}{|c|}{$\mathrm{kg} \mathrm{ha}^{-1}$} & \multicolumn{2}{|c|}{$\$ \mathrm{ha}^{-1}$} \\
\hline None & No & $720 \mathrm{~b}$ & $1620 c$ & $-112 b$ & $288 \mathrm{c}$ \\
\hline$S$-metolachlor & No & $930 \mathrm{a}$ & $3420 b$ & $-57 \mathrm{ab}$ & $1118 b$ \\
\hline S-metolachlor plus fomesafen & No & $1120 \mathrm{a}$ & $3990 \mathrm{a}$ & $48 \mathrm{a}$ & $1415 \mathrm{a}$ \\
\hline None & Yes & $940 \mathrm{a}$ & $3820 \mathrm{a}$ & $-31 \mathrm{ab}$ & $1339 a$ \\
\hline$S$-metolachlor & Yes & $1000 \mathrm{a}$ & $4070 \mathrm{a}$ & $-56 a b$ & $1408 \mathrm{a}$ \\
\hline S-metolachlor plus fomesafen & Yes & $1040 \mathrm{a}$ & $4200 a$ & $-34 \mathrm{ab}$ & $1471 \mathrm{a}$ \\
\hline
\end{tabular}

${ }^{a}$ Means within a column followed by the same letter are not significantly different according to Fisher's Protected LSD test at $P \leq 0.05$. Data are pooled over herbicide resistance traits and soybean populations.

${ }^{\mathrm{b}} S$-metolachlor and $S$-metolachlor plus fomesafen applied at 1500 and $1200+270 \mathrm{~g} \mathrm{ha}^{-1}$, respectively.

${ }^{c}$ Postemergence herbicides included glufosinate and glyphosate applied to appropriate herbicide-resistant cultivars at 560 and $840 \mathrm{~g}^{-1} \mathrm{a}^{-1}$, respectively.

TABLE 11: Soybean yield and estimated economic return as influenced by herbicide resistance trait, soybean plant population, and postemergence herbicide treatment during 2011 in Fields B13 and C11. ${ }^{\mathrm{a}}$

\begin{tabular}{|c|c|c|c|c|c|c|c|c|c|}
\hline \multirow{5}{*}{$\begin{array}{l}\text { Soybean } \\
\text { population }^{\text {b }}\end{array}$} & \multirow{5}{*}{$\begin{array}{l}\text { Post } \\
\text { herbicide }^{c}\end{array}$} & \multirow{2}{*}{\multicolumn{4}{|c|}{$\begin{array}{c}\text { Soybean yield } \\
\text { Herbicide resistance trait }\end{array}$}} & \multicolumn{4}{|c|}{ Economic return } \\
\hline & & & & & & \multicolumn{4}{|c|}{ Herbicide resistance trait } \\
\hline & & \multicolumn{2}{|c|}{ Field B13 } & \multicolumn{2}{|c|}{ Field C11 } & \multicolumn{2}{|c|}{ Field B13 } & \multicolumn{2}{|c|}{ Field C11 } \\
\hline & & Glufosinate & Glyphosate & Glufosinate & Glyphosate & Glufosinate & Glyphosate & Glufosinate & Glyphosate \\
\hline & & \multicolumn{4}{|c|}{$\mathrm{kg} \mathrm{ha}^{-1}$} & \multicolumn{4}{|c|}{$\$ \mathrm{ha}^{-1}$} \\
\hline Low & No & $1420 c$ & $540 \mathrm{c}$ & $2860 c$ & $1980 c$ & $224 \mathrm{c}$ & $-237 c$ & $924 \mathrm{c}$ & $481 \mathrm{c}$ \\
\hline Low & Yes & $2180 \mathrm{~b}$ & $2290 b$ & $3790 b$ & $3620 b$ & $544 \mathrm{~b}$ & $601 b$ & $1326 b$ & $1263 a b$ \\
\hline High & No & $2240 b$ & $2680 \mathrm{~b}$ & $3620 b$ & $3580 \mathrm{~b}$ & $507 \mathrm{bc}$ & $705 b$ & $1201 b$ & $1153 b$ \\
\hline High & Yes & $3720 a$ & $3850 a$ & $4560 a$ & $4150 \mathrm{a}$ & $1195 a$ & $1255 a$ & $1625 a$ & $1408 \mathrm{a}$ \\
\hline
\end{tabular}

${ }^{a}$ Means within a column followed by the same letter are not significantly different according to Fisher's Protected LSD test at $P \leq 0.05$. Data are pooled over preemergence herbicides.

${ }^{\mathrm{b}}$ Low soybean populations in Fields B13 and C11 during 2011 was 221,000 and 208,000 plants $\mathrm{m}^{-2}$, respectively. High soybean populations in these fields were 560,000 and 519,000 plants $\mathrm{m}^{-2}$, respectively.

${ }^{\mathrm{c}}$ Glufosinate and glyphosate applied to appropriate herbicide-resistant cultivar at 560 and $840 \mathrm{~g} \mathrm{ha}^{-1}$, respectively.

fomesafen was applied, the Palmer amaranth population decreased to 10 plants $\mathrm{m}^{-2}$ or less. No difference in Palmer amaranth density was noted when comparing $S$-metolachlor and $S$-metolachlor plus fomesafen. When activated by rainfall or irrigation, these herbicides often control Palmer amaranth for several weeks during the season [22].

The interaction of soybean population by POST herbicide was significant for Palmer amaranth control in Field E2 during 2010. When pooled over HRT and PRE herbicides, control was 50 to $55 \%$ without POST herbicides (data not shown in tables). Applying a POST herbicide to the low seeding rate increased control to $81 \%$, while the combination of the high seeding rate and POST herbicide controlled Palmer amaranth $94 \%$ (data not shown in tables). Soybean population also influenced the interaction of PRE herbicide and HRT in this field. In absence of PRE herbicides, Palmer amaranth was controlled more effectively when glufosinate was applied in the high population compared with the low population (Table 3). The most effective control in this HRT was $S$-metolachlor plus fomesafen in the high population. Although PRE herbicides increased control when glyphosate was applied, control was not affected by soybean population (Table 3). In contrast to these results, soybean population did not interact with HRT or herbicide treatments in Fields B13 and C11. When pooled over HRT and PRE and POST herbicides, Palmer amaranth control was greater in Fields B13 (2010) and C11 (2011) when soybean was planted at a higher population compared with control at lower soybean populations (control of $75 \%$ versus $64 \%$ and $72 \%$ versus $67 \%$, resp., data not shown in tables).

An interaction of PRE by POST by HRT was observed in Field E2 during 2010. In the absence of POST herbicides, Palmer amaranth control by $S$-metolachlor exceeded that of no PRE herbicide while $S$-metolachlor plus fomesafen was more effective than $S$-metolachlor alone (Table 4). Applying glufosinate or glyphosate after a residual PRE herbicide increased control over each POST herbicide alone.

In Fields B13 during both years and Field C11 in 2011, the interaction of PRE and POST herbicide was significant for Palmer amaranth control. S-metolachlor plus fomesafen was more effective than $S$-metolachlor alone in 2 of 3 fields when POST herbicides were not applied and in 1 of 3 fields when POST herbicides were applied (Table 5). As expected, impact of PRE herbicides on Palmer amaranth control was minimized when POST herbicides were applied compared with no POST herbicide, although control increased in 2 
of 3 fields when $S$-metolachlor plus fomesafen was applied compared with no PRE herbicide.

The interaction of POST herbicides and HRT was significant for Palmer amaranth control in Field B13 during 2010. When pooled over soybean populations and PRE herbicides, Palmer amaranth control increased from $57 \%$ to $81 \%$ (glufosinate) and $43 \%$ to $94 \%$ (glyphosate) (data not shown in tables). Additionally, the value of PRE herbicides was noted for both HRT, with $S$-metolachlor plus fomesafen being the most effective PRE treatment (Table 6).

In Field E3 during 2011, the interaction of soybean population, PRE herbicide, POST herbicide, and HRT was significant for Palmer amaranth control. Increasing the soybean population increased Palmer amaranth control from 83 to $85 \%$ to $98 \%$ when $S$-metolachlor was applied alone (Table 7). This response was not observed when POST herbicides were applied. $S$-metolachlor plus fomesafen controlled Palmer amaranth at least 95\% regardless of soybean population or POST herbicides.

Soybean yield during 2010 was low compared with yield during 2011 due to dry conditions throughout most of the growing season. Soybean yield was higher in Fields E2 during 2010 and Field E3 during 2011 when the soybean population increased independent of PRE or POST herbicides and HRT (Table 8). Applying $S$-metolachlor alone or with fomesafen increased yield over no PRE in each of these fields. Increasing the soybean population increased estimated economic return for Field E3 during 2011 (Table 9). Applying S-metolachlor or $S$-metolachlor plus fomesafen increased estimated economic return over no PRE treatment. Additionally, applying a POST herbicide increased estimated economic return (Table 9).

Soybean yield and economic return were affected by the interaction of PRE and POST herbicides in Field B13 and C11 during 2011. In Field B13, a POST herbicide did not increase yield compared with no POST herbicides when $S$ metolachlor or $S$-metolachlor plus fomesafen were applied (Table 10). The lowest yield in this field was noted when neither PRE nor POST herbicides were applied. In Field C11, yield was similar when $S$-metolachlor plus fomesafen were applied irrespective of POST herbicides or when a POST herbicide was applied irrespective of PRE herbicide treatment. Estimated economic return reflected soybean yield in Field C11. In Field B13, no difference in economic return was noted among treatments except when comparing the no PRE or POST treatment with $S$-metolachlor plus fomesafen.

The interaction of soybean population by POST herbicide by HRT was significant for both yield and estimated economic return in Fields B13 and C11 in 2011. Increasing the soybean population and applying either glufosinate or glyphosate increased yield in both fields compared with yield at lower soybean populations with or without POST herbicides (Table 11). Applying a POST herbicide in the low population or not including a POST herbicide in the higher population affected yield similarly in both fields. The lowest yield was noted in absence of POST herbicides at the lowest soybean population. Estimated economic return reflected yield in Field B13 for glyphosate and for glufosinate in Field
C11. In Field B13 following glufosinate, the highest estimated economic return was noted after glufosinate was applied at the higher soybean population. Applying glyphosate resulted in similar estimated economic returns regardless of soybean population in Field C11. In the absence of POST herbicides, estimated economic return was greater with the higher soybean population.

\section{Conclusions}

Results from the survey during 2010 reveal the magnitude of Palmer amaranth infestation in soybean in North Carolina after weed control programs had been implemented (39\% of fields surveyed). Palmer amaranth control did not differ in most cases when comparing glufosinate with glyphosate, most likely because frequency of glyphosate resistance was relatively low in these fields (10\% or less) and because POST herbicides were applied when Palmer amaranth was relatively small based on manufacturer and Cooperative Extension recommendations. The combination of $S$-metolachlor plus fomesafen PRE was often very effective in controlling Palmer amaranth in these experiments. The most consistent control across years and field sites was noted when PRE herbicides were followed by a POST herbicide. Currently, this strategy is used by many growers in North Carolina to control Palmer amaranth in soybean and other crops. However, concern has been expressed that even though herbicides that inhibit protoporphyrinogen oxidase, such as fomesafen, are effective in controlling Palmer amaranth, over reliance on herbicides with this mode of action could lead to resistance [23]. Therefore, cultural practices such as increased seeding rate, as investigated in this study, may become increasingly important in managing Palmer amaranth and other weeds where concern over herbicide resistance exists [14]. Although some variation was noted among combinations of HRT and PRE herbicides in our study, a higher soybean population often increased Palmer amaranth control, soybean yield, and estimated economic return. Even though production costs are higher with elevated seeding rates, results suggest that seeding rates that are higher than those necessary under weed-free conditions to optimize yield can be established without a negative impact on economic return when Palmer amaranth is present. While not documented in these studies, minimizing Palmer amaranth reproduction is an important management practice in soybean and other crops, especially in fields where herbicide resistance is present.

\section{Conflict of Interests}

None of the authors has a conflict of interests in terms of the products mentioned in the paper.

\section{Acknowledgments}

This research was supported by grower check off funds administered through The North Carolina Soybean Growers Association. Southern States Cooperative, Inc. and Monsanto provided the soybean seed used in these experiments. 
Charlie Cahoon, Peter Eure, Jamie Hinton, Rick Seagroves, Sam Wells, and staff at the Upper Coastal Plain Research Station provided technical assistance.

\section{References}

[1] I. Heap, "The international survey of herbicide resistant weeds," 2012, http://www.weedscience.org.

[2] J. R. Whitaker, Distribution, Biology, and Management of Glyphosate-Resistant Palmer Amaranth in North Carolina [PhD dissertation], North Carolina State University, Raleigh, NC, USA, 2009.

[3] A. S. Culpepper, A. C. York, A. W. MacRae, and J. Kichler, "Glyphosate-resistant Palmer amaranth response to weed management programs in Roundup Ready and Liberty Link cotton," in Proceedings of the Beltwide Cotton Conferences, National Cotton Council, Nashville, Tenn, USA, January 2008.

[4] L. M. Sosnoskie, J. M. Kichler, R. D. Wallace, and A. S. Culpepper, "Multiple resistance in Palmer amaranth to glyphosate and pyrithiobac confirmed in Georgia," Weed Science, vol. 59, no. 3, pp. 321-325, 2011.

[5] A. E. Hoffner, D. L. Jordan, and A. C. York, "Geographical distribution of herbicide resistance in Palmer amaranth (Amaranthus palmeri) populations across North Carolina," in Proceedings of the 7th International IPM Symposium: IPM on the World Stage, pp. 27-29, Memphis, Tenn, USA, March 2012.

[6] A. S. Culpepper, T. L. Grey, W. K. Vencill et al., "Glyphosateresistant Palmer amaranth (Amaranthus palmeri) confirmed in Georgia," Weed Science, vol. 54, no. 4, pp. 620-626, 2006.

[7] T. M. Webster, "Weed survey—southern states: broadleaf crop subsection," in Proceedings of the Southern Weed Science Society's meeting, vol. 62, pp. 517-520, 2005.

[8] J. R. Whitaker, A. C. York, D. L. Jordan, and A. S. Culpepper, "Palmer amaranth (Amaranthus palmeri) control in soybean with glyphosate and conventional herbicide systems," Weed Technology, vol. 24, no. 4, pp. 403-410, 2010.

[9] D. B. Harder, C. L. Sprague, and K. A. Renner, "Effect of soybean row width and population on weeds, crop yield, and economic return," Weed Technology, vol. 21, no. 3, pp. 744752, 2007.

[10] G. T. Place, S. C. Reberg-Horton, E. J. Dunphy, and A. N. Smith, "Seeding rate effects on weed control and yield for organic soybean production," Weed Technology, vol. 23, no. 4, pp. 497-502, 2009.

[11] T. C. Mueller, P. D. Mitchell, B. G. Young, and A. S. Culpepper, "Proactive versus reactive management of glyphosate-resistant or -tolerant weeds," Weed Technology, vol. 19, no. 4, pp. 924933, 2005.

[12] M. D. K. Owen, "Weed species shifts in glyphosate-resistant crops," Pest Management Science, vol. 64, no. 4, pp. 377-387, 2008.

[13] D. R. Shaw, M. D. Owen, P. M. Dixon et al., "Benchmark study on glyphosate-resistant cropping systems in the United States. Part 1: introduction to 2006-2008," Pest Management Science, vol. 67, no. 7, pp. 741-746, 2011.

[14] D. A. Guillermo, P. Pedersen, and R. G. Hartzler, "Soybean seeding rate effects on weed management," Weed Technology, vol. 23, no. 1, pp. 17-22, 2009.

[15] O. W. Howe and L. R. Oliver, "Influence of soybean (Glycine max) row spacing on pitted morningglory (Ipomoea Lacunose) interference," Weed Science, vol. 35, pp. 185-193, 1987.

[16] G. R. W. Nice, N. W. Buehring, and D. R. Shaw, "Sicklepod (Senna obtusifolia) response to shading, soybean (Glycine max) row spacing, and population in three management systems," Weed Technology, vol. 15, no. 1, pp. 155-162, 2001.

[17] J. K. Norsworthy and J. R. Frederick, "Reduced seeding rate for glyphosate-resistant, drilled soybean on the southeastern coastal plain," Agronomy Journal, vol. 94, no. 6, pp. 1282-1288, 2002.

[18] J. K. Norsworthy and L. R. Oliver, "Effect of seeding rate of drilled glyphosate resistant soybean (Glycine max) on seed yield and gross profit margin," Weed Technology, vol. 15, pp. 284-292, 2001.

[19] R. J. Kratochvil, J. T. Pearce, and M. R. Harrison Jr., "Row spacing and seeding rate effects on glyphosate-resistant soybean for mid-Atlantic production systems," Agronomy Journal, vol. 96, no. 4, pp. 1029-1038, 2004.

[20] North Carolina Department of Agriculture and Consumer Services, "Crops summary: field crops, fruits,vegetables," 2010, http://www .ncagr.gov/stats/crops/CropSummary.pdf.

[21] G. Bullen, E. J. Dunphy, and E. Weddington, "Soybean budgetfull season, conventional tillage," 2010, North Carolina Cooperative Extension, http://www.ag-econ.ncsu.edu/extension/ budgets/wheat/SoybeanFullConv2010.pdf.

[22] W. J. Everman, "Chemical weed control in soybeans," Pages 253-263 in 2012 North Carolina Agricultural Chemicals Manual, Pub. AG-1, 430 pages, 2012.

[23] M. D. K. Owen and I. A. Zelaya, "Herbicide-resistant crops and weed resistance to herbicides," Pest Management Science, vol. 61, no. 3, pp. 301-311, 2005. 


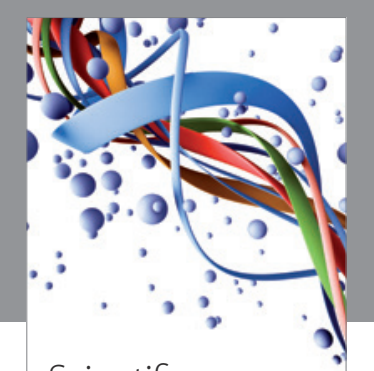

Scientifica
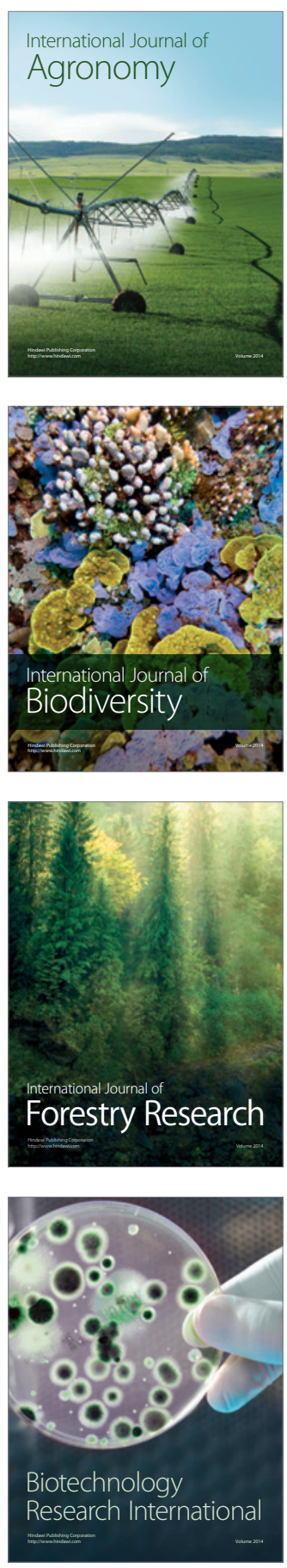
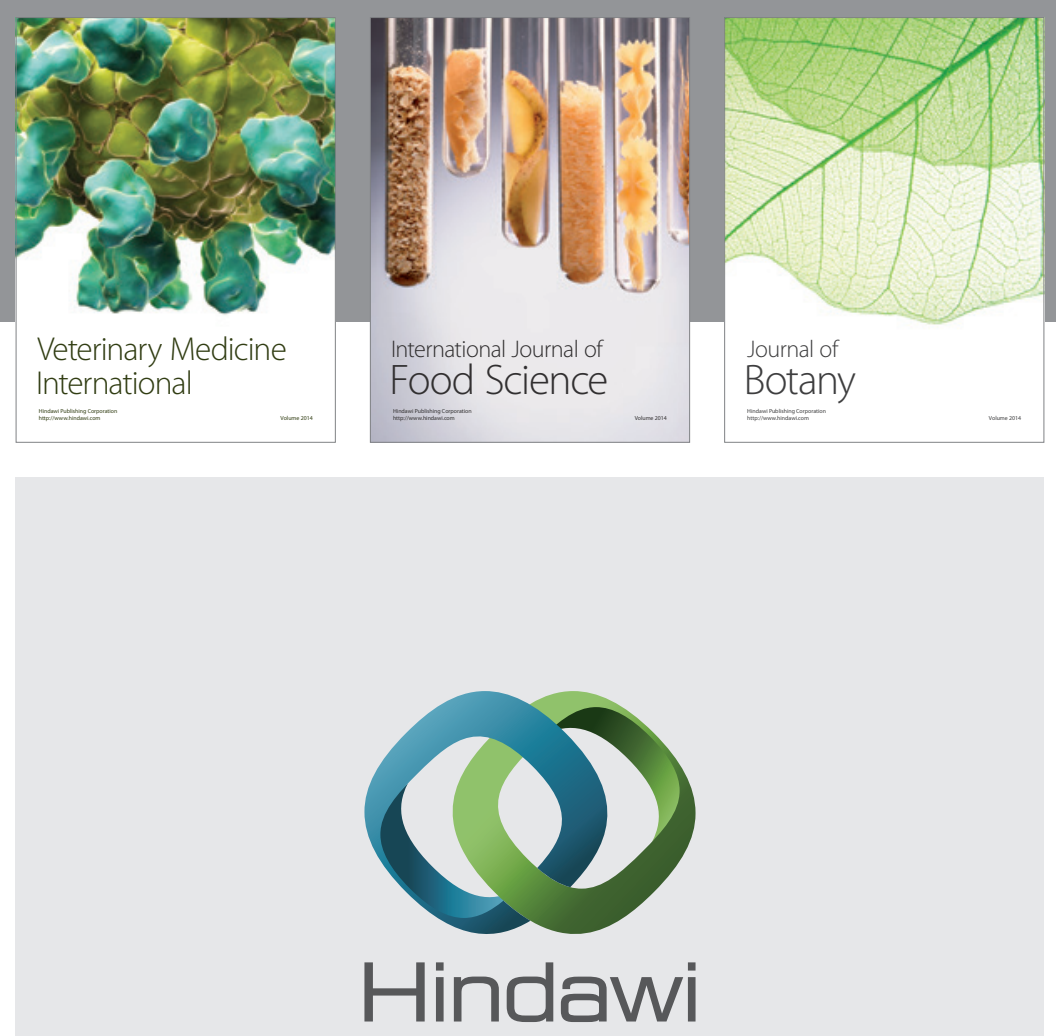

Submit your manuscripts at

http://www.hindawi.com
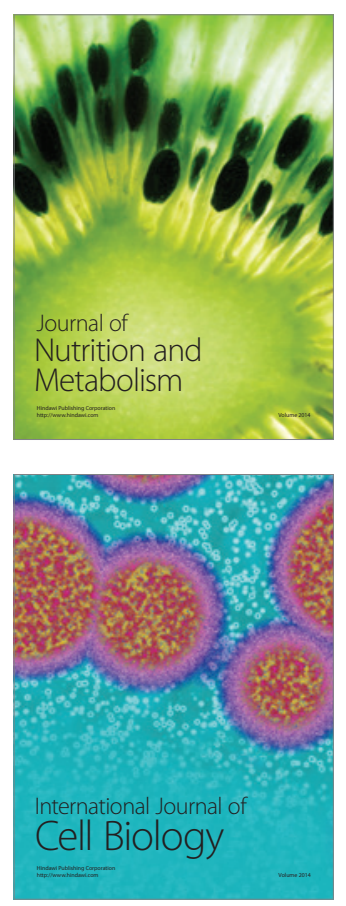
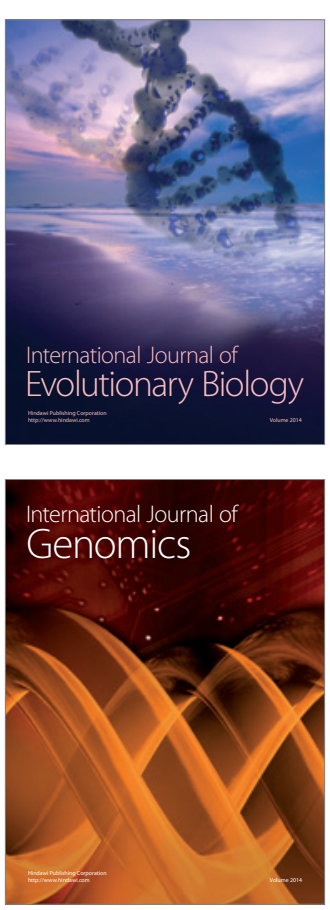
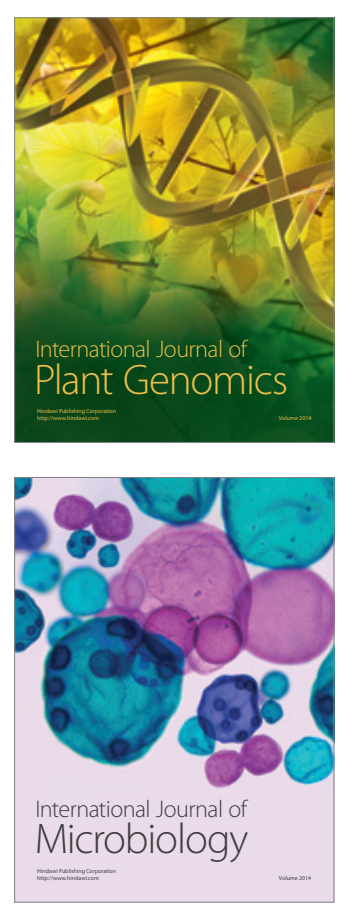

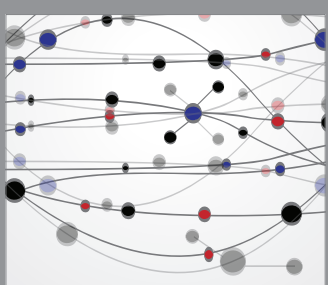

The Scientific World Journal
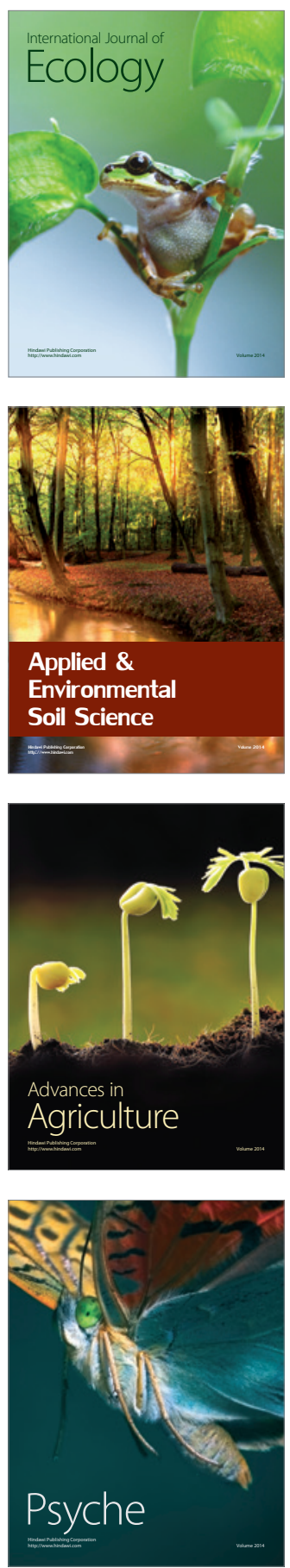